\title{
Food Consumption Pattern and Nutritional Status of Women in Orissa: A Rural-Urban Differential
}

\author{
Nihar Ranjan Rout \\ Post-Graduate Department of Population Studies, Fakir Mohan University, \\ Balasore 756019 , Orissa, India \\ E-mail:nihar_rout@rediffmail.com
}

KEYWORDS Body Mass Index (BMI). Food Intake. Malnutrition. Rural. Anemia

\begin{abstract}
As per the estimates of National Family Health Survey, Orissa lies far behind the national average in terms of many important aspects of nutrition. The problem is definitely more acute in case of the women staying in rural areas. This paper tries to find out the variation in food consumption and nutritional status of women in the state in rural and urban areas against different background variables. It also attempts to capture the difference between standard and actual level of food intake among different groups of women. The current study is based on NFHS - II data, which comprised of 4425 ever married women in the age group $15-49$. As expected, a profound variation in nutritional status was observed between the rural and urban women in Orissa. 33 percent of urban women and 48.6 percent of rural women were found to be in the low BMI group. As far as food consumption was concerned, urban women enjoyed a better position in all the food items. Nutritional status was found to be positively related with education of respondent, education of husband, household standard of living, occupation of husband. However, the variation in nutritional status was not found to be very high between different categories of any explanatory or background variable in rural areas. Most of the rural women when categorized were found to be taking less food than their requirement. All these clearly suggest a condition of emergency for improving the nutritional status of women in Orissa, especially in the rural areas.
\end{abstract}

\section{INTRODUCTION}

There is no doubt that India has made substantial progress in human development during the post-independence period. Prior to independence, many people in the country were not even being able to dream of a square meal everyday. However, as an attempt to boost the agricultural production by modernizing the technique of farming in the country, Green Revolution during 1960 s contributed a great deal in solving the food problem and making the country self sufficient in food. According to Measham and Chaterjee (1999), Green Revolution provided a breathing spell for the country by achieving a balance between human numbers and food output. The overall nutritional status has definitely improved during last few decades. Still, more than half of Indian children under five years of age are moderately or severely malnourished, 30 percent of newborns are significantly underweight and 60 percent of Indian women are anemic and such manifestations of malnutrition are certainly unacceptable (Measham and Chaterjee 1999). Thus it can be well said that improvements in nutritional status have not kept pace with progress in other areas of human development, at least when homogenous distribution is taken into consideration.

In the words of Rousseau, "Where there is no mother, there can be no child. Their duties are reciprocal; and if they are badly fulfilled on one side, they will be neglected on the other ...". This quotation is very appropriate to the subject of adequate nutrition for each woman. The belief that a woman should eat better foods and more foods (for pregnant women) is as old and has been held by both the extremes- laymen and scientists (Fleck and Henrietta 1971). But there has been a gap between the thought and the action. This study aims at providing a database showing the exact picture of Orissa regarding food, nutrition and health.

According to Swaminathan (1982), good nutrition is a function of both economy and education. And as revealed by Ronzio (2004), women are usually vulnerable to malnutrition for both social and biological reasons, throughout their life cycle. As children in some parts of the world, girls are discriminated against in access to health care, to food and education and in other ways. As teenagers, they risk of early pregnancy and suffer with more risk of retarded growth than boys. Reproductive aged women are subject to 
numerous stresses affecting the health and wellbeing. Elderly women in many societies are deprived too. Thus there exists an intergenerational cycle of growth failure for women. Poor nutrition as such, is very much poverty driven and it remains entangle inside a vicious circle. As shown in Figure 1, the present study is more concerned about women's background variables affecting the food consumption practice, which in turn affects the nutritional status.

\section{OBJECTIVES}

1. To assess the nutritional status of women in Orissa using different anthropometric measures and to explore the rural urban differentials.

2. To draw a comparative picture of the food consumption pattern between rural and urban women of Orissa.

3. To examine the impact of various background variables on the nutritional status of women in Orissa.

4. Creating an index to check the difference between standard and actual level of food intake among different groups of women, both in rural and urban areas separately.

\section{MATERIALS AND METHODS}

The present study is based on raw data from National Family Health Survey (1998-99), which comprised of 4425 eligible women form 4689 number of households in Orissa. The sample size was 3937 for rural and 488 for urban areas, where the ever-married women in the age group 15-49 were interviewed. These women were weighed using a solar powered digital scale with an accuracy of $+100 \mathrm{gm}$ and their height were measured using an adjustable wooden measuring board with an accuracy level of $0.1 \mathrm{~cm}$. For finding out anemia, haemoglobin levels were tested for 97 percent women (4282) in Orissa. Women with a haemoglobin level less than $7 \mathrm{gm} / \mathrm{dl}$ in blood were grouped as severe anemic and those between $7 \& 9.9 \mathrm{gm} / \mathrm{dl}$, as moderate anemic. Incase of pregnant women the range for mild anemia was kept as 10 to 10.9 and incase of nonpregnant women it was kept as 10 to 11.9 . Anything beyond that level came under no anemic group as per NFHS definition.

The raw data of NFHS-II for the state of Orissa was taken as such in the SPSS format and the variables were recorded as per the requirement. Then to achieve the first two objectives, bivariate analysis (cross tabulation) was done and logistic regression was run for meeting the third objective. As the food consumption levels were supposed to get described by the standard of living variable to a large extent, those variables were not taken into account and the religion was dropped from the analysis due to very low cell frequency in the categories other than the Hindu. Obesity (BMI>25) was included in the normal BMI group due to very low prevalence of the same in Orissa, which made an easy dichomatization of the dependent variable, BMI.

\begin{tabular}{|c|c|c|}
\hline Background characteristics & Food consumption practice & Nutritional status \\
\hline $\begin{array}{l}\text { Age } \\
\text { Education } \\
\text { Caste } \\
\text { Religion } \\
\text { Residence } \\
\text { Working Status } \\
\text { Standard of Living } \\
\text { Husband's education } \\
\text { Husband's occupation } \\
\text { Life style }\end{array}$ & $\begin{array}{l}\text { Milk or Curd } \\
\text { Pulses or beans } \\
\text { Green leafy vegetables } \\
\text { Other vegetables } \\
\text { Fruits } \\
\text { Chicken/Meat/Fish } \\
\text { Egg }\end{array}$ & $\begin{array}{l}\text { Height } \\
\text { Weight } \\
\text { BMI } \\
\text { Anemia }\end{array}$ \\
\hline
\end{tabular}

Fig. 1: Working Framework showing relationship between background characteristics and nutritional status 
For the fourth objective, first of all, foods were grouped into three categories i.e. high caloric (chicken, meat, fish, egg), moderately caloric (milk, curd, pulses, beans) and low caloric (leafy and other vegetables, fruits), depending upon their actual calorie content and were given weights as 3,2 and 1 respectively with respect to their calorie content proportion. Then weights of 3,2 and 1 were given to the women consuming the food daily, weekly and occasionally respectively. Such a calculation is always very arbitrary as there was no question asked about the amount of food taken in NFHS. However, from these two, a composite value suggesting the actual food intake, fore each woman was computed.

Then the women were grouped into four categories depending upon their per day calorie requirement (as shown in Table 1), namely pregnant, non pregnant -non worker, non pregnant - office worker and non pregnant-other workers. Here two point were assumed:

(i) All the women are involved in their own domestic work irrespective of their occupational status.

(ii) Women do work a bit less than their usual average during their pregnancy period.

Table 1: Per day calorie requirement of different categories of women and approximate standard values of food intake

\begin{tabular}{ccc}
\hline Type of women & Calorie required/day & Standard value \\
\hline $\begin{array}{c}\text { Pregnant } \\
\text { Non pregnant- } \\
\text { nonworking }\end{array}$ & $2500 \mathrm{cal}$ & $2500 \times \mathrm{x} \mathrm{k}$ \\
$\begin{array}{c}\text { Non pregnant- } \\
\text { office worker }\end{array}$ & $2200 \mathrm{cal}$ & $1800 \mathrm{x} \mathrm{k}$ \\
$\begin{array}{c}\text { Non pregnant- } \\
\text { other worker }\end{array}$ & $2800 \mathrm{cal}$ & $2200 \mathrm{x} \mathrm{k}$ \\
\hline
\end{tabular}

Then the mean values for each women group separately for rural and urban areas ( 8 groups in total) was calculated and the deviations form the standard values were plotted on the graph. One more thing that was assumed here was that, the difference in food standard is only due to the difference in the working status of women and not due to their residential differences i.e., rural and urban.

The balance diet for a pregnant woman was considered and after assigning the values for both food types and frequency of consumption, a value of 22 was obtained, for those women. It was equated with the per-day required calorie intake for computing the multiplier $(\mathrm{K})$, which was obtained to be 22/2500. Apart from it variation in
BMI among pregnant and non pregnant women in both rural and urban areas were also computed from the raw data.

\section{ANALYSIS OF FINDINGS}

Here the unit of analysis is ever-married woman in the age group 15 to 49 . As per the standard definition adopted by NFHS, Body Mass Index (BMI) is divided into three groups, namely low, normal and high, linked with under nutrition, average nutrition and over nutrition respectively. Height has been recorded into three groups like les than $145 \mathrm{~cm}, 145$ to $155 \mathrm{~cm}$. and above $155 \mathrm{~cm}$, keeping in mind that height below $145 \mathrm{~cm}$ leads to complication during child birth and that below $155 \mathrm{~cm}$ is below standard. Similarly weight has been recorded into less than $40 \mathrm{~kg}$, $40-50 \mathrm{~kg}$, and over $50 \mathrm{~kg}$.

Table 2 revealed the variation of nutritional status of women in rural and urban areas of Orissa. As far as height was concerned 13.2 percent of the urban women were below $145 \mathrm{~cm}$; ; whereas the figure was 15.2 percent for the rural women in Orissa. On the other hand, among the urban women, 23.7 percent possessed a height more than $155 \mathrm{~cm}$.; but the figure was only 19.8 per cent for their rural counterparts. The situation was same for weight also. 22.9 percent urban women and 34.6 percent of rural women fell in the category of below $40 \mathrm{~kg}$ and only 14.9 percent of the rural women weighed more than $50 \mathrm{~kg}$ against a figure of 31.3 percent in case of urban women.

Table 2: Rural - Urban differentials in percentage distribution of ever married women in Orissa with respect to their nutritional status categories

\begin{tabular}{lrrr}
\hline Variables & Rural & Urban & Total \\
\hline Height $(\mathrm{cm})$. & & & \\
$\quad<145$ & 13.2 & 15.2 & 15.0 \\
$\quad 145-155$ & 63.0 & 65.5 & 65.2 \\
$\quad>155$ & 23.7 & 19.3 & 19.8 \\
Weight $(\mathrm{kg})$. & & & \\
$\quad<40$ & 22.9 & 34.5 & 33.0 \\
$\quad 40-50$ & 45.8 & 52.8 & 52.1 \\
$\quad>50$ & 31.3 & 12.7 & 14.9 \\
BMI $\left(\mathrm{kg} . / \mathrm{m}^{2}\right)$ & & & \\
$\quad$ 18.5 & 33.0 & 48.6 & 46.9 \\
$\quad 18.5-25$ & 54.0 & 48.1 & 48.7 \\
$\quad>25$ & 13.0 & 3.3 & 4.4 \\
Anemia & & & \\
$\quad$ No & 45.4 & 36.2 & 37.2 \\
$\quad$ Mild & 41.2 & 45.8 & 45.3 \\
$\quad$ Moderate & 11.9 & 16.4 & 15.9 \\
$\quad$ Severe & 1.5 & 1.6 & 1.6 \\
\hline
\end{tabular}


Coming to the summary index BMI, in urban areas 33 percent of women possessed low BMI $\left(<18.5 \mathrm{~kg} . / \mathrm{m}^{2}\right)$ whereas almost half of the rural women (48.6 percent to be specific) came under the same category. As far as obesity was concerned, rural women were in a better position with only 3.3 percent of them being above $25 \mathrm{~kg} /$ $\mathrm{m}^{2}$ BMI, whereas the figure was 13 percent for the urban women.

Regarding the food consumption pattern differential (as shown in table 3 ) rural women in Orissa were not found to be better consumers, even for a single food item. 62.9 percent and 26.4 percent of urban women were eating 'pulses or beans' and 'milk or curd' daily, respectively, but the figures were only 37.5 percent ad 8.1 percent

Table 3: Rural - urban differentials in percentage distribution of ever married women in Orissa with respect to their food consumption pattern

\begin{tabular}{|c|c|c|c|}
\hline Food consumption & Urban & Rural & Total \\
\hline \multicolumn{4}{|l|}{ Milk/Curd } \\
\hline Daily & 26.4 & 8.1 & 10.1 \\
\hline Weekly & 13.3 & 10.2 & 10.6 \\
\hline Occasionally & 46.6 & 62.5 & 60.7 \\
\hline Never & 13.5 & 19.2 & 18.6 \\
\hline \multicolumn{4}{|l|}{ Pulses/Beans } \\
\hline Daily & 62.9 & 37.5 & 40.3 \\
\hline Weekly & 27.9 & 42.0 & 40.4 \\
\hline Occasionally & 8.2 & 19.4 & 18.2 \\
\hline Never & 1.0 & 1.1 & 1.1 \\
\hline \multicolumn{4}{|c|}{ Green Leafy Vegetables } \\
\hline Daily & 59.5 & 55.7 & 56.1 \\
\hline Weekly & 32.7 & 35.1 & 34.8 \\
\hline Occasionally & 7.6 & 9.0 & 8.9 \\
\hline Never & 0.2 & 0.2 & 0.2 \\
\hline \multicolumn{4}{|l|}{ Other Vegetables } \\
\hline Daily & 88.3 & 77.7 & 78.9 \\
\hline Weekly & 8.8 & 18.0 & 17.0 \\
\hline Occasionally & 2.9 & 4.3 & 4.2 \\
\hline Never & 0 & 0 & 0 \\
\hline \multicolumn{4}{|l|}{ Fruits } \\
\hline Daily & 4.9 & 2.2 & 2.5 \\
\hline Weekly & 23.4 & 10.5 & 11.9 \\
\hline Occasionally & 69.3 & 82.3 & 80.8 \\
\hline Never & 2.5 & 5.1 & 4.8 \\
\hline \multicolumn{4}{|l|}{ Eggs } \\
\hline Daily & 2.0 & 0.6 & 0.8 \\
\hline Weekly & 29.2 & 14.8 & 14.8 \\
\hline Occasionally & 46.4 & 58.1 & 58.1 \\
\hline Never & 22.3 & 26.3 & 26.3 \\
\hline \multicolumn{4}{|l|}{ Chicken/Meat/Fish } \\
\hline Daily & 3.7 & 1.6 & 1.5 \\
\hline Weekly & 42.3 & 26.7 & 26.7 \\
\hline Occasionally & 43.8 & 65.3 & 65.3 \\
\hline Never & 10.2 & 6.5 & 6.5 \\
\hline \multicolumn{4}{|l|}{ Food Habit } \\
\hline Non-vegetarian & 90.4 & 94.6 & 94.1 \\
\hline Vegetarian & 9.6 & 5.4 & 5.9 \\
\hline
\end{tabular}

for their rural counterparts. The difference, however, was not so much in case of vegetables; but there also urban women were in a better position. As far as fruits, eggs, chicken or meat or fish were concerned, the figures were 4.9 percent, 2.0 percent, and 3.7 percent respectively for urban women ad 2.2 percent, 0.6 percent and 1.6 percent for their rural counterparts, clearly indicating the lower status of rural women in Orissa regarding consumption of food. 46 percent of urban women were taking chicken or meat or fish at least once in a week; but the figure was only 28.3 percent in rural areas. However the share of non-vegetarian among the respective sample was more in rural areas (94.6 percent) than in the urban areas ( 90.4 percent).

As shown in table 4 , in rural areas the BMI was found to be very much same for all the age groups, but in urban areas it experienced a tremendous increase with age. 50 percent of urban women in the age group 15-24 possessed a BMI more than equal to $18.5 \mathrm{~kg} / \mathrm{m}^{2}$, whereas for the age group 35-49, the figure became 76 percent. However, with increase in the level of education of either the respondent or her husband, BMI status increased both in rural and urban areas. With a better occupational type of respondent's husband, the BMI tended to increase; though in rural areas the pace was not the same as in the urban areas. As expected, it was found that better the standard of living more the body mass index was, and it was true irrespective of rural or urban status of the locality. But 86.8 percent of high standard of living group possessed a BMI of more than equal to $18.5 \mathrm{~kg} / \mathrm{m}^{2}$ in urban areas whereas the figure was 75.6 percent in rural areas under the same condition.

It was evident from Table 5 that with decreasing frequency of consumption of various food items, more women were found to be in the category of low BMI, in comparison to those in normal BMI group, both in urban as well as in rural areas. For example, the ratio of percentage of women in normal BMI group to that in low BMI group was calculated to be 4.65 for those consuming milk/ curd daily in urban areas, where as the figure came down to 2.76 for those consuming milk/ curd weekly, 1.51 for those with occasional consumption and a low of 1.24 for those women who never consumed milk. The trend was found to be quite similar in case of rural area also. However, the pace was found to be comparatively higher in case of urban areas 
Table 4: Rural - Urban differentials in percentage distribution of ever married women in Orissa with respect to their BMI levels against background variables

\begin{tabular}{|c|c|c|c|c|}
\hline \multirow[t]{2}{*}{ Variable } & \multicolumn{2}{|c|}{ Urban } & \multicolumn{2}{|c|}{ Rural } \\
\hline & $<18.5$ & $>=18.5$ & $<18.5$ & $>=18.5$ \\
\hline \multicolumn{5}{|l|}{ Age } \\
\hline $15-24$ & 50.0 & 50 & 49.1 & 50.9 \\
\hline $25-34$ & 33.8 & 66.2 & 49.6 & 50.4 \\
\hline $35-49$ & 24.0 & 76.0 & 47.2 & 52.8 \\
\hline \multicolumn{5}{|l|}{ Education } \\
\hline Illiterate & 52.5 & 47.5 & 53.3 & 46.7 \\
\hline Literate up to middle & e 21.3 & 78.7 & 42.6 & 57.4 \\
\hline Middle complete & 32.7 & 67.3 & 42.2 & 57.8 \\
\hline High school \& above & e 16.2 & 83.8 & 32.2 & 67.8 \\
\hline \multicolumn{5}{|c|}{ Occupation } \\
\hline Not working & 28.4 & 71.6 & 47.2 & 52.8 \\
\hline White collar job & 28.9 & 71.1 & 34.9 & 65.1 \\
\hline Agro-related & 45.5 & 54.5 & 55.0 & 45.0 \\
\hline $\begin{array}{l}\text { Domestic \& } \\
\text { other services }\end{array}$ & 64.3 & 35.7 & 26.3 & 73.7 \\
\hline Manual worker & 62.8 & 37.2 & 54.6 & 45.4 \\
\hline \multicolumn{5}{|l|}{ Religion } \\
\hline Hindu & 33.1 & 66.9 & 48.8 & 51.2 \\
\hline Others & 32.5 & 67.5 & 44.7 & 55.3 \\
\hline \multicolumn{5}{|l|}{ Ethnicity } \\
\hline $\mathrm{SC}$ & 50.6 & 49.4 & 52.9 & 47.1 \\
\hline ST & 48.8 & 51.2 & 54.3 & 45.7 \\
\hline $\mathrm{OBC}$ & 32.0 & 68.0 & 49.2 & 50.8 \\
\hline None of them & 23.9 & 76.1 & 39.9 & 60.1 \\
\hline \multicolumn{5}{|l|}{ Standard of Living } \\
\hline Low & 57.5 & 42.5 & 53.7 & 46.3 \\
\hline Medium & 32.5 & 67.5 & 46.1 & 53.9 \\
\hline High & 13.2 & 86.8 & 24.4 & 75.6 \\
\hline \multicolumn{5}{|c|}{ Husband's Education } \\
\hline Illiterate & 57.6 & 42.4 & 55.7 & 44.3 \\
\hline Literate up to middle & e 35.7 & 64.3 & 49.0 & 51.0 \\
\hline Middle complete & 31.7 & 68.3 & 43.7 & 56.3 \\
\hline High school \& above & e 20.0 & 80.0 & 35.4 & 64.6 \\
\hline \multicolumn{5}{|c|}{ Husband's Occupation } \\
\hline Not working & 33.3 & 66.7 & 44.8 & 55.2 \\
\hline White collar job & 22.4 & 77.6 & 38.5 & 61.5 \\
\hline Agro-related & 36.6 & 63.4 & 51.6 & 48.4 \\
\hline $\begin{array}{l}\text { Domestic \& } \\
\text { other services }\end{array}$ & 28.6 & 71.4 & 43.7 & 56.3 \\
\hline Manual worker & 46.2 & 53.8 & 50.5 & 49.5 \\
\hline
\end{tabular}

than in the rural areas. For example the ratio of percentage of women in normal BMI group to that in low BMI group was found to be 1.53 and 0.93 respectively for those women who were consuming milk/ curd daily and who were never consuming milk/ curd in rural areas, where as the counter figures were 4.65 and 1.24 respectively for urban women. The scenario and trend was quite similar in case of other food items like pulses/ beans, vegetables, and fruits as well as nonvegetarian food items.

As evident from table 6, urban women enjoyed a better condition, as they were 1.3 times more likely to fall under more than equal to $18.5 \mathrm{~kg} / \mathrm{m}^{2}$
Table 5: Rural - Urban differentials in percentage distribution of ever married women in Orissa with respect to their BMI levels against food consumption pattern

\begin{tabular}{|c|c|c|c|c|}
\hline \multirow{2}{*}{$\begin{array}{l}\text { Food consumption } \\
\text { pattern }\end{array}$} & \multicolumn{2}{|c|}{ Urban } & \multicolumn{2}{|c|}{ Rural } \\
\hline & $<18.5$ & $>=18.5$ & $<18.5$ & $>=18.5$ \\
\hline \multicolumn{5}{|l|}{ Milk/Curd } \\
\hline Daily & 17.7 & 82.3 & 39.5 & 60.5 \\
\hline Weekly & 26.6 & 73.4 & 48.9 & 51.1 \\
\hline Occasionally & 39.9 & 60.1 & 48.8 & 51.2 \\
\hline Never & 44.6 & 55.4 & 51.9 & 48.1 \\
\hline \multicolumn{5}{|l|}{ Pulses/Beans } \\
\hline Daily & 25.2 & 74.8 & 41.7 & 58.3 \\
\hline Weekly & 46.6 & 53.4 & 52.3 & 47.7 \\
\hline Occasionally & 47.5 & 52.5 & 54.1 & 45.9 \\
\hline Never & 20.0 & 80.0 & 46.5 & 53.5 \\
\hline \multicolumn{5}{|c|}{ Green Leafy Vegetables } \\
\hline Daily & 31.6 & 68.4 & 48.1 & 51.9 \\
\hline Weekly & 33.1 & 66.9 & 49.7 & 50.3 \\
\hline Occasionally & 43.2 & 55.6 & 48.2 & 51.8 \\
\hline Never & 100.0 & 0.0 & 42.9 & 57.1 \\
\hline \multicolumn{5}{|l|}{ Other Vegetables } \\
\hline Daily & 31.4 & 68.6 & 46.7 & 53.3 \\
\hline Weekly & 40.5 & 59.5 & 54.6 & 45.4 \\
\hline Occasionally & 64.3 & 35.7 & 58.8 & 41.2 \\
\hline \multicolumn{5}{|l|}{ Fruits } \\
\hline Daily & 17.4 & 82.6 & 35.4 & 64.6 \\
\hline Weekly & 28.3 & 71.7 & 45.7 & 54.3 \\
\hline Occasionally & 34.5 & 65.6 & 49.3 & 50.7 \\
\hline Never & 66.7 & 33.3 & 49.5 & 50.5 \\
\hline \multicolumn{5}{|l|}{ Eggs } \\
\hline Daily & 11.1 & 86.9 & 43.5 & 56.5 \\
\hline Weekly & 29.8 & 70.2 & 46.1 & 53.9 \\
\hline Occasionally & 40.9 & 59.1 & 50.0 & 50.0 \\
\hline Never & 23.4 & 76.6 & 47.1 & 52.9 \\
\hline \multicolumn{5}{|l|}{ Chicken/Meat/Fish } \\
\hline Daily & 33.3 & 66.7 & 57.8 & 42.2 \\
\hline Weekly & 26.2 & 71.8 & 43.5 & 56.5 \\
\hline Occasionally & 40.3 & 59.7 & 50.2 & 49.8 \\
\hline Never & 20.4 & 79.6 & 50.4 & 49.6 \\
\hline \multicolumn{5}{|l|}{ Food Habit } \\
\hline Non-vegetarian & 34.4 & 65.6 & 48.6 & 51.4 \\
\hline Vegetarian & 19.6 & 80.4 & 49.5 & 50.5 \\
\hline
\end{tabular}

category of BMI. Apart from type of residence, standard of living and education of respondent were found to describe the dependent variable significantly. With reference to the low standard of living group, women those in medium group were 1.158 times more likely to be in normal BMI group and the figure was 2.67 time for those in high standard of living group. Education was also found to describe the BMI status positively, with women with up to middle, and high school and above education were 1.25 and 1.28 times more likely to be in the more than equal to $18.5 \mathrm{~kg} / \mathrm{m}^{2}$ $\mathrm{BMI}$ category respectively. In case of caste, OBC and other category were in a slight better position; but the relationship was not so significant. Surprisingly, husband's occupation 
was not coming as significant as it was expected. Still women with husbands in white collar jobs were 1.06 times more likely to be in the more than equal to $18.5 \mathrm{~kg} / \mathrm{m}^{2}$ category with reference to those without working husbands. As suggested by the table, in case of age, women with higher age (30-49) were 1.15 times more likely to be in the normal BMI group as compared to those in younger ages (15-29). As far as life style was concerned, women with a habit of chewing tobacco or taking alcohol or smoking were less likely to be in the normal BMI group; but the relationship was not so significant.

Table 7 shows the deviation in actual food intake from the standard for different categories of women in the state. It was very clear from the graph (Fig. 2) that all types of women in rural areas, except the non-working category, fell below the standard level, whereas except those in nonpregnant non-workers category, all other types of women in urban areas were above the standard level. In fact in rural areas, majority of the females categorized as workers are from the needy households with comparatively lower level of socio - economic development. In turn, many a times women from the better off households

Table 6: Logistic Regression* between BMI $(<18.5$ $\mathrm{kg} / \mathrm{m}^{2} \&>=18.5 \mathrm{~kg} / \mathrm{m}^{2}$ ) of Ever Married Women in Orissa and Background Characteristics

\begin{tabular}{|c|c|c|}
\hline $\begin{array}{l}\text { Variables and } \\
\text { categories }\end{array}$ & $\begin{array}{c}\text { Significance } \\
\text { level }\end{array}$ & $\begin{array}{c}\text { Exponential } \\
(B)\end{array}$ \\
\hline \multicolumn{3}{|l|}{ Type of Residence (Rural) } \\
\hline Urban & 0.017 & 1.308 \\
\hline \multicolumn{3}{|l|}{ Age Group (15-29) } \\
\hline $30-49$ & 0.033 & 1.149 \\
\hline \multicolumn{3}{|l|}{ Caste $(S C \& S T)$} \\
\hline OBC \& Others & 0.264 & 1.083 \\
\hline \multicolumn{3}{|l|}{ Standard of Living (Low) } \\
\hline Medium & 0.056 & 1.156 \\
\hline High & 0 & 2.672 \\
\hline \multicolumn{3}{|c|}{ Respondent's Education (Illiterate) } \\
\hline Literate up to middle & 0.007 & 1.248 \\
\hline High school \& above & 0.162 & 1.276 \\
\hline \multicolumn{3}{|c|}{ Husband's Education (Illiterate) } \\
\hline Literate up to middle & 0.037 & 1.177 \\
\hline High school \& above & 0.046 & 1.298 \\
\hline \multicolumn{3}{|c|}{ Respondent's Occupation (Not Working) } \\
\hline Working & 0.011 & 1.039 \\
\hline \multicolumn{3}{|c|}{ Husband's Occupation (Not Working) } \\
\hline Agricultural \& Domestic & $=0.429$ & 0.861 \\
\hline Manual & 0.637 & 0.913 \\
\hline White collar & 0.764 & 1.061 \\
\hline \multicolumn{3}{|l|}{ Life Style (With Habit) } \\
\hline Without habit & 0.366 & 1.063 \\
\hline Constant & 0.08 & 0.701 \\
\hline
\end{tabular}

*Reference categories shown in parentheses
Table 7: Composite Food Intake index Values and Deviation from Standard among Ever Married Women in different categories in Orissa

\begin{tabular}{lccc}
\hline Type of women & $\begin{array}{c}\text { Actual } \\
\text { value }\end{array}$ & $\begin{array}{c}\text { Standard } \\
\text { value }\end{array}$ & $\begin{array}{c}\text { Devia- } \\
\text { tion }\end{array}$ \\
\hline A) Non Pregnant & 19.51 & 15.84 & 3.67 \\
$\begin{array}{l}\text { Non Worker } \\
\text { (Rural) }\end{array}$ & 19.26 & 19.36 & -0.1 \\
B) $\begin{array}{l}\text { Non Pregnant } \\
\text { Office worker } \\
\text { (Rural) }\end{array}$ & & & \\
C) $\begin{array}{l}\text { Non Pregnant } \\
\text { Other Workers } \\
\text { (Rural) }\end{array}$ & 17.67 & 24.64 & -6.97 \\
D) $\begin{array}{l}\text { Pregnant Women } \\
\text { (Rural) }\end{array}$ & 19.6 & 22 & -2.4 \\
E) $\begin{array}{l}\text { Non Pregnant } \\
\text { Non Worker } \\
\text { (Urban) }\end{array}$ & 22.42 & 15.84 & 6.58 \\
F) $\begin{array}{l}\text { Non Pregnant } \\
\text { Office Worker } \\
\text { (Urban) }\end{array}$ & 24.12 & 19.36 & 4.76 \\
G) $\begin{array}{l}\text { Non Pregnant } \\
\text { Other Workers } \\
\text { (Urban) }\end{array}$ & 20.07 & 24.64 & -4.57 \\
H) Pregnant Women & 23.49 & 22 & 1.49 \\
$\quad$ (Urban) & & & \\
\hline
\end{tabular}

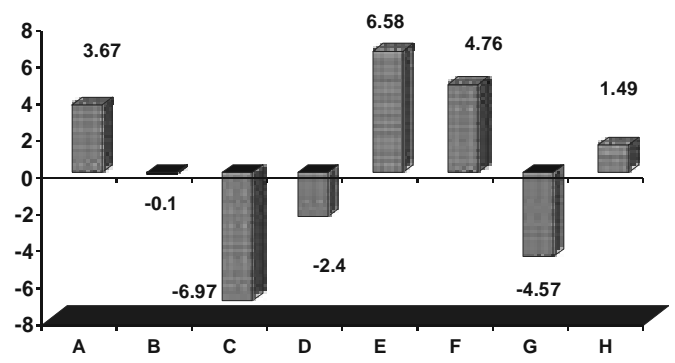

Fig. 2. Deviation in actual food intake from standard among different categories of women

remain as non-workers in rural areas. Therefore, non-working women in the rural areas experienced a positive deviation from the standard value, as far as composite food intake index was concerned. On the other hand those urban women categorized as 'other workers' are supposed to be engaged in different jobs mostly as construction workers or daily labourers in the unorganized sector, leading to a more likely chance of being in the economically deprived group. However, considering the fact that majority of sample was under the belt of rural category, it could be well inferred that Oriya women lag a lot as far as nutritional status was concerned. 


\section{SUMMARYAND CONCLUSION}

As expected, a profound variation in nutritional status was observed between the rural and urban women in Orissa. 33 percent of urban women and 48.6 percent of rural women were found to be in the low BMI group. Mean height of urban women was slightly more than that of rural women and the case was same for weight also. Share of vegetarian was found to be more in urban than rural areas. As far as food consumption was concerned, urban women enjoyed a better position in all the food items. Nutritional status was found to be positively related with education of respondent, education of husband, household standard of living. A better occupational type of respondent's husbands also resulted in a better nutritional status of the women. However, the variation in nutritional status was not found to be very high between different categories of any explanatory or background variable in rural areas. Most of the rural women when categorized were found to be taking less food than their requirement.

All these clearly suggest a condition of emergency for improving the nutritional status of women in Orissa, especially in the rural areas. Every effort must be made to develop and implement relevant strategies designed to improve health of women. Special care must be taken regarding nutritional status of "adolescent girls" in the rural areas. This area is definitely an important aspect of the overall health strategy, which needs to be put into action within no time. This must go hand in hand with a programme of nutrition education. With the help of appropriate mass media, pregnant women and mothers should be educated about nutrition and health and so also the general public regarding issues related to health and nutrition.

\section{REFERENCES}

Fleck Henrietta 1971. Introduction to Nutrition. London: The Macmillan Company, Collier-Macmillan Limited.

IIPS 1999: Report of National Family Health Survey -II, India. Mumbai: International Institute for Population Sciences.

IIPS 1999: Report of National Family Health Survey -II, Orissa. Mumbai: International Institute for Population Sciences.

Measham AR, Chaterjee Meera 1999. Wasting Away: The Crisis of Malnutrition in India. Washington DC: World Bank.

Ronzio Robert 2004. The Encyclopedia of Nutrition and Good Health. New Delhi: Viva Books Private Ltd.

Swaminathan MS 1982. Handbook of Food and Nutrition. Bangalore: The Bangalore Printing and Publishing Co. Limited. 